\title{
ACERCA DA ADAPTAÇÃO AOS EXTREMOS CLIMÁTICOS, A GESTÃO E A REDUÇÃO DE RISCOS DE DESASTRES NA AMÉRICA LATINA E CARIBE.
}

\author{
ACERCA DE LA ADAPTACIÓN A LOS EXTREMOS CLIMÁTICOS, GESTIÓN Y \\ REDUCCIÓN DEL RIESGO DE DESASTRES EN AMÉRICA LATINA Y EL CARIBE.
}

\section{ABOUT THE EXTREME CLIMATE CHANGES ADAPTATION AND DISASTER RISKS MANAGEMENT AND REDUCTION IN THE LATIN AMERICA AND CARIBBEAN REGION.}

\author{
Ronaldo Lyrio BORGO. ${ }^{1}$
}

RESUMO: Um plano estratégico com base na cooperação intergovernamental dentro do contexto da integração de infra-estruturas na América Latina e no Caribe pode ser acordado no âmbito da União de Nações Sul-Americanas UNASUL e da Comunidade de Estados Latino Americanos e Caribenhos CELAC, para enfrentar os grandes desafios de suportar o ciclo estratégico completo de gestão e redução de desastres, gerando resiliências para adaptação e mitigação em conformidade com os principais temas de ações políticas recomendadas pelo Framework para Desenvolvimento de Políticas do Clima da UN-UNEP, e para gerenciar emergências em situações de desastres naturais causados principalmente pelos extremos climáticos na região. Esta iniciativa regional ALC para empreender a sua estrutura/plataforma proprietária no século XXI, é um novo desafio para as políticas de ciências e tecnologias, no sentido de aderir e persistir na busca austera para alcançar sustentabilidade em geral . Este artigo propõe uma pequena e breve contribuição para este plano, que deve ser coberto por parcerias estratégicas internacionais e uma vasta experiência em aplicações de Ciências e Tecnologias para Adaptação às Mudanças Climáticas.

Palavras-chave: Adaptação, mudanças climáticas extremas, Região da ALC, Programa de Cooperação em Ciência Tecnologia e Inovação.

\footnotetext{
1- Applied Telecommunications Electrical Engineer Master. Expertise in Information Society Technology: Science and Technology Policy Management. Had beeen working during 20 years with public and private corporations on planning and management of engineering projects in Brazil, Africa and South America. Actualy works as Senior Analyst of Science and Technology of the National Council of Technological and Scientific Development CNPq. He served as Executive Coordinator of the CNPq/UNDP International Cooperation Project for the Brazilian Information Society. Collaborator with the Brazilian Commission for Communications CBC-4 from ANATEL, with the Study Group 3 - "Information and communication infrastructure and technology development, emergency telecommunications and climate change adaptation”. E-mail: rborgo@cnpq.br; rlbaquarius@gmail.com
} 
RESUMEN: Un plan estratégico basado en la cooperación intergubernamental y la integración de infraestructuras en América Latina y el Caribe podría acordarse dentro de la Unión de Naciones Suramericanas (UNASUR) y de la Comunidad de Estados Latino americanos y Caribeños (CELAC) para enfrentar los enormes retos de proporcionar la gestión y la reducción de desastres, generando resiliencia para la adaptación y mitigación de acuerdo con los temas principales de las acciones políticas recomendadas por el Marco de Desarrollo de Políticas del Clima del PNUMA, y para gestionar las emergencias en situaciones de desastres naturales causados principalmente por condiciones climáticas extremas. La iniciativa de la región para mejorar su propio marco en el siglo XXI es un nuevo desafío de las políticas de ciencias y tecnologías pueden unirse y persistir en la búsqueda austera para la sostenibilidad general. En este trabajo se propone una contribución pequeña y breve a este plan, que debe ser cubierto por las alianzas estratégicas internacionales y una amplia experiencia en aplicaciones de Ciencias y Tecnologías para la Adaptación al Cambio Climático.

Palabras clave: adaptación, cambios climáticos extremos, la región LAC, Programa de Cooperación Ciencia y Tecnología

\begin{abstract}
A strategic plan based on intergovernmental cooperation under the infrastructures integration in Latin America and the Caribbean could be agreed within the Union of South American Nations UNASUR and the Latin America and Caribe states Community CELAC to face the tremendous challenges of providing management and reduction for disaster situations, generating resilience engineering for adaptation and mitigation in accordance with the main themes of political actions recommended by the UN-UNEP Policy Development Framework for Climate, and to manage emergencies in situations of natural disasters caused mainly by climate extremes hazards. The region initiative to improve its own framework in the XXI century is a new S\&T policy challenge to adhere and persist in the austere search for general sustainability. This paper proposes a small and brief contribution to this plan, which must be covered by international strategic partnerships and extensive experience in applications of Sciences and Technologies for Adaptation to Climate Change.
\end{abstract}

Key words: Adaptation, extreme climate changes, LAC region Science \& Technology Cooperation Program.

\title{
I- INTRODUCTION
}

A practical approach about adaptation to climate extremes it no longer only supports the main vision focused on disaster risk reduction. However when analyzing the purposeful actions of 
the UNEP framework of Fig. 1 for adaptation, it is seen how some appropriate engineering expertise it is applied for every action concerning the use of systems and technology platforms for environmental monitoring, planning, integration, control and management, as well as for preparedness and response to disasters, in accordance with the disaster management cycle seen in the Fig.2.[5]

Among several efforts to tackle the immense problems caused by natural disasters mostly linked to climatic extremes, there is a strong call from the international bodies connected with the UN, as the UNEP to support disaster prevention policies to reduce levels of risk impacts or hazards due to the scenarios of vulnerabilities, it means creating general resilience against disaster risks vulnerabilities[6]. These powerfull strategic paradigm it grows like a XXI century oddisey to face develop technical and social skills to ensure humanitarian acceptable levels of sustainability.

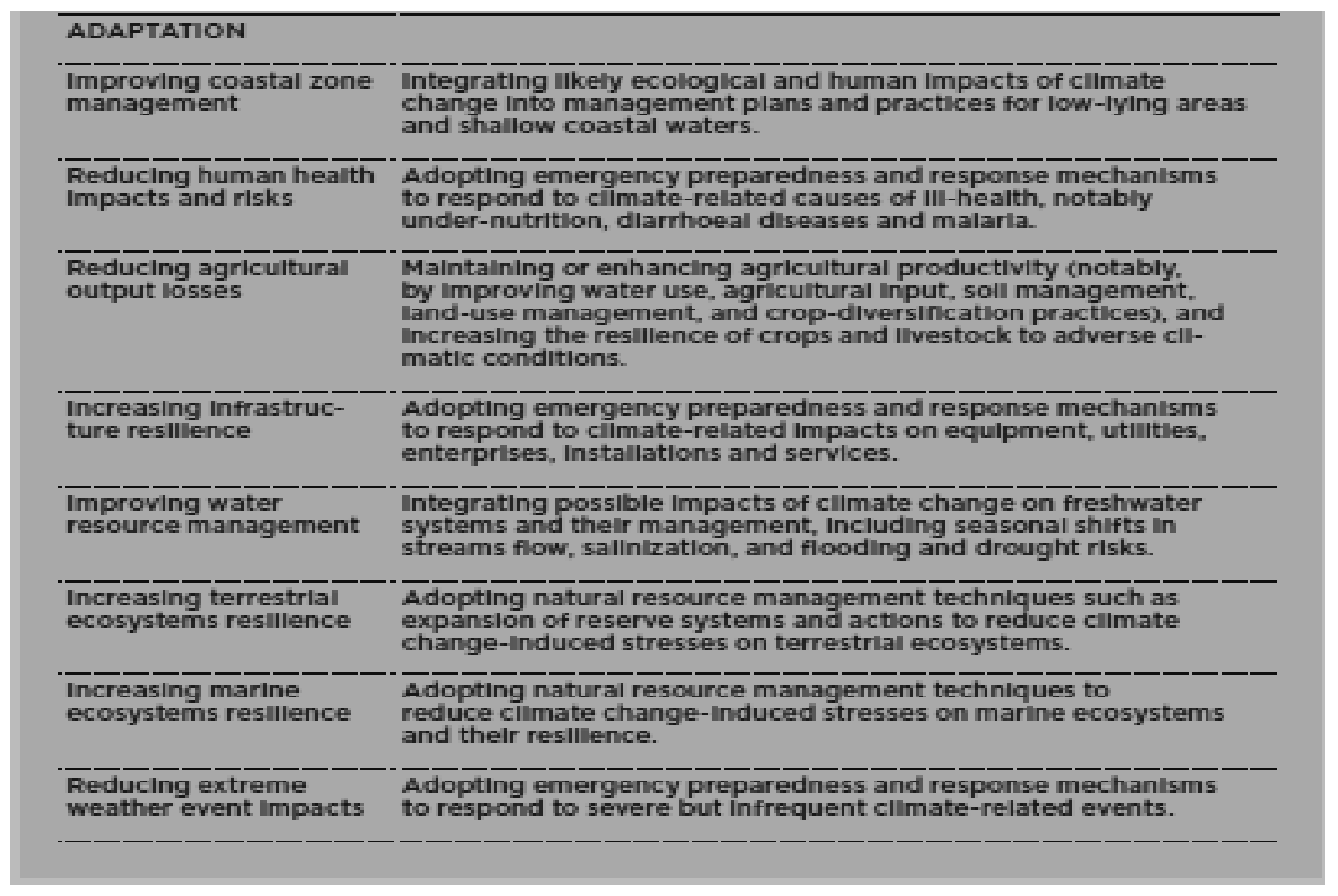

Fig. 01 - Purposeful actions of the UNEP Climate Policy framework [5] 


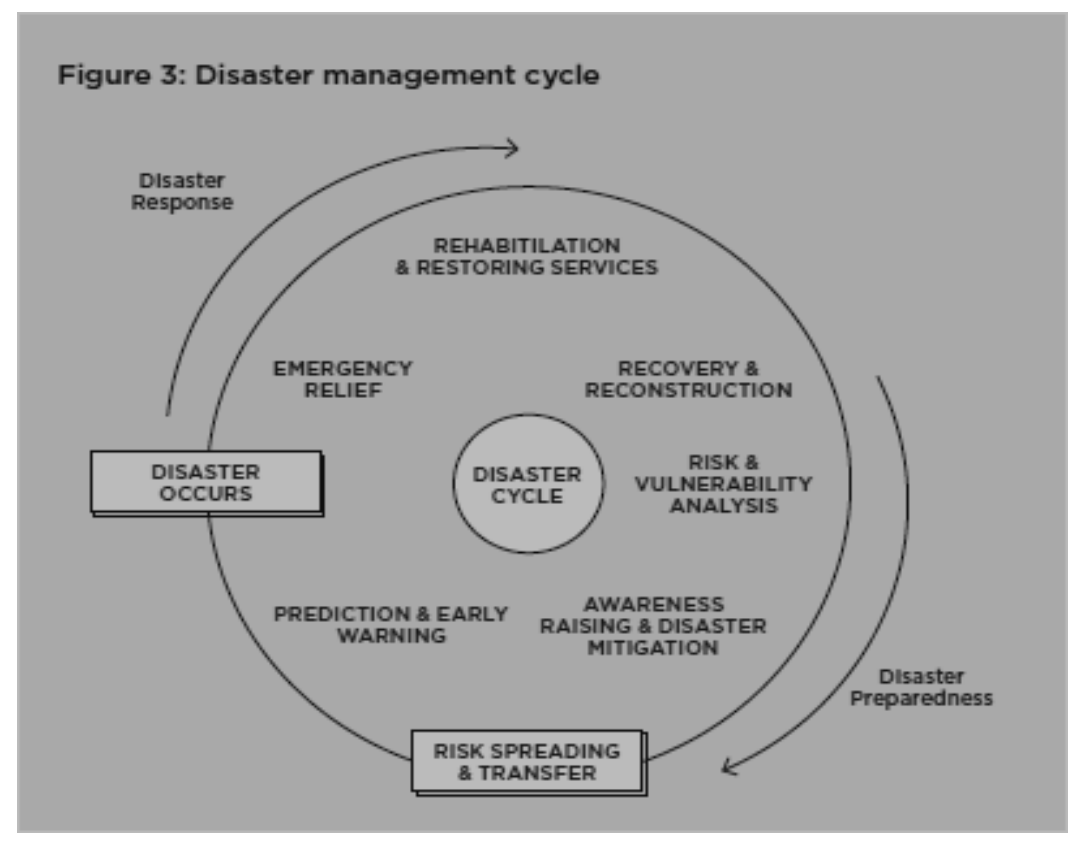

Fig. 02 - Disaster Management Cycle [ 5]

\section{II- LAC Region Scenario aspects and Motivations}

Major national efforts were promoted by the countries of the Latin America region, which includes the Mexico, Central America, the Caribbean and South America, to develop their security and disaster risk management integrated systems and networks. Among several national policy frameworh actions to promote technology platforms to support full management and disaster reduction initiatives, Brazil already have two major centers for integrated disaster management: The National Center for Disaster Response CENAD, and the National Center for Natural Disaster Monitoring and Alert CEMADEN, and a technical cooperation agreement between the Brazilian Space Agency (AEB) and Japanese Space Agency (JAXA) to develop satellites applied to disaster management. Even so, Ecuador has installed a integrated National Center for Disaster Management and Security in a joint technical cooperation with China, and has a International Center CIIFEN for the El Niño Investigation doing the climate change adaptation and disaster risk reduction as a focal Western South America point of the World Meteorological 
Organization WMO, and of the UN International Strategy for Disaster Reduction UN-ISDR. Even with these major national's oriented S\&T policy initiatives in South America, the region has no dedicated and integrated technical platform holding full support for the complete cycle of management and disaster risk reduction, it could be implemented as a region framework intensively based on Information and broadband communication and information technological infrastructures integrated on terrestrial and space satellite telecommunications networks. The LAC region it is understood as the 2 nd region of the world hardest hit by hydrometeorological disasters with economic losses of around 1\% of GDP [4]. Figures 04 illustrate these estimated economic data and information.

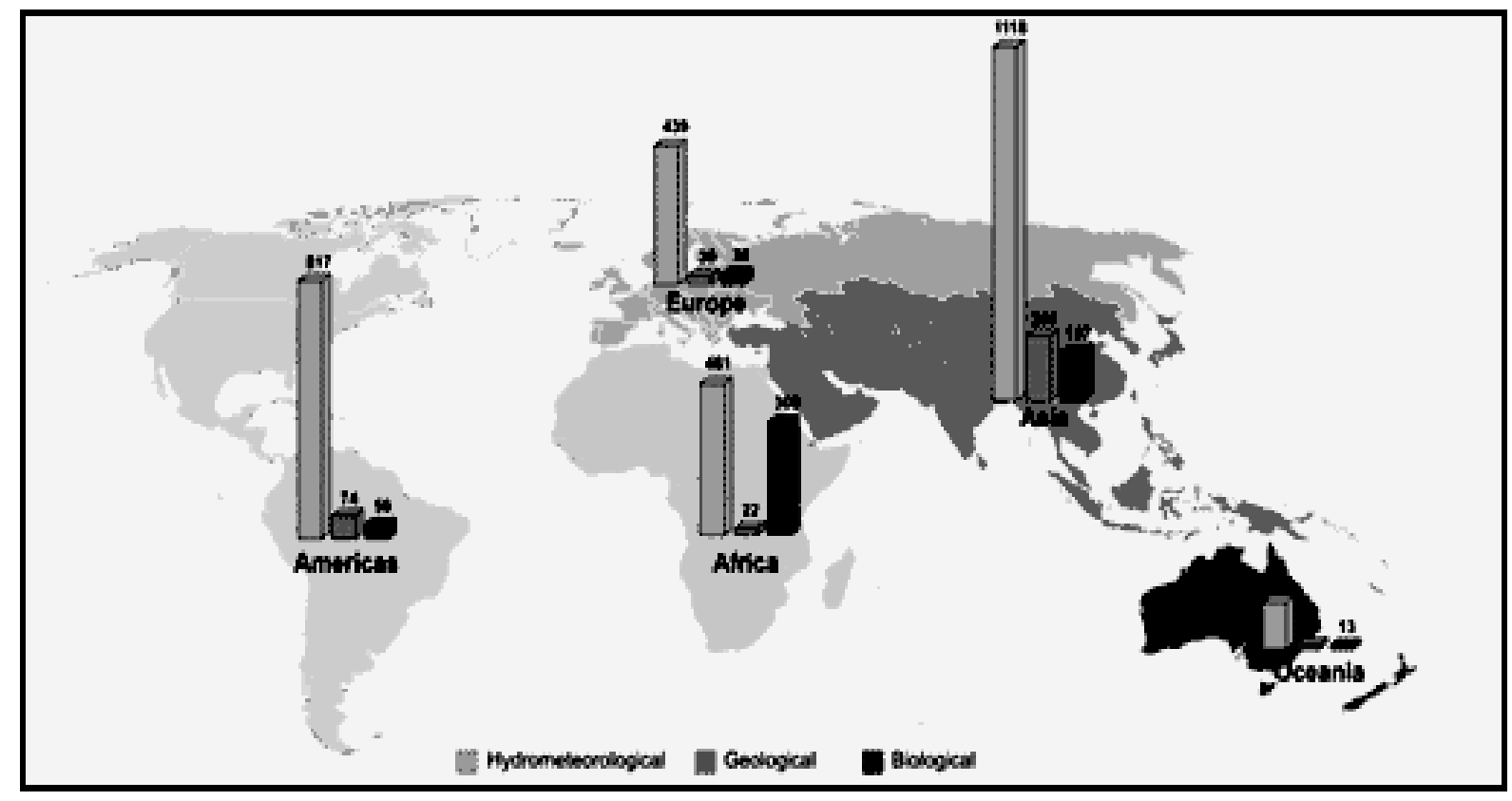

Figure 03 - Regional distribution and number of natural disasters from 1995 to 2004. Source: UNEP / DEWA / GRID-Europe, November 2004.[1]

The Economic Commission for Latin America and the Caribbean (ECLAC) report released at the 2010 United Nations Climate Change Conference (COP-16) placed a loss margin of around 1\% of GDP as the escalating disater economic loss due to the extreme climate changes hazard impacts in the LAC region, not having reached consensus on actions to mitigate climate, starting from 2010. It is worth mentioning the findings of the report [4] the weights around these estimates and scenarios of vulnerability in the region: 
It means that a sustainable, adaptative, low-carbon, socially inclusive development strategy must be designed and implemented. This strategy must be based on awareness that economic growth which does not take into account climate-related phenomena and considerations of equality will be quite likely to prove unsustainable in the long run.

In fact, in temperate countries could be lost the equivalent of about $1 \%$ of annual GDP throughout the period of analysis, ie to 2100 under the A2 scenario, which exceeds the budget of the ministries of environment. These costs would be higher in the Andean countries, Central America and the Caribbean. Moreover, in some cases, such as those affecting biodiversity or human life, will not economically quantifiable irreversible consequences. How tolerable is dramatic or balance is closely linked to emissions scenario. The ongoing climate change and adaptation is inevitable in the region.

This loss scale factor represents only infrastructure and economic assets losses and does not measure the loss of nation's lifes. Such values from disasters exceed some nation's budget in the LAC region, and undertake all efforts to invest in development, integration and sustainability. The annual estimate disaster economic loss for Brazil is around units of US\$ billions, and for the LAC region around tens of US\$ billions, they are linear estimations to have a scale like values of economic losses dimension $[2,3]$.

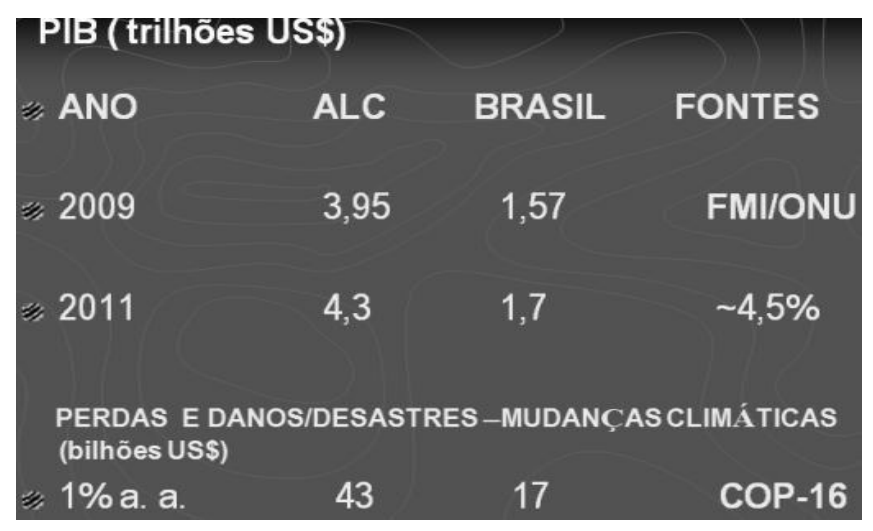

Figure 04 - Scale Disaster loss estimation based on ECLAC report.[3,4] 


\section{III - Estimates and Prospects for Implementation of a Disaster Management and risk reduction dedicated and integrated Scientific and Technological Platform in LAC region.}

The LAC region Science and Technology cooperative framework Police Initiative to project and construct a dedicated and integrated Scientific and Technological Platform applied to disaster risk reduction and management, it was budget minimum estimated margin range nearly around $10 \%$ to $20 \%$ of the annual economic losses due to disasters in the region, considering a simulated budget for a infrastructure composition based on the US technical platforms improvements notices during the last century [3]. The infrastructure integration agreements for development of the Union of South American Nations (UNASUR) and the Community of Latin American and Caribbean States (CELAC), they could promote in the near future (2016), an integrated and dedicated regional technical platform based on Information and broadband Communication technological infrastructure for disaster risk reduction and management. The terrestrial segment could be composed of national disaster management stations and local centers as nodes of the disaster management network, and a geostationary satellite constellation in the space segment, for shared and cooperative multiple use of the south sub-region 02 of the ITU-R (LAC) illustrated in Figure 1.3, as the example of the actions and programs for research and developments already implemented in the others regions: 01(UE) and 03( Asia Pacific), and North sub-region 2 of the ITU-R.

The shared applications, cover since teaching and learning, environmental monitoring and management, research, development and scientific-technological innovation, public protection, disaster risk reduction and recovery to human safety and health $[1,2]$.

The EU part of the Sub-region 01 , the North-America tpart of the region 02, and the Asia-Pacific or sub-region 03 of the ITU-R, they offers a huge experience on R \& D \& I information and communication systems to support full management and disaster reduction, especially for the second sub-region 02 comprising Latin America and Caribe [1]. The development model can start with a pilot program for a integrated South America regional platform from Brazil and Ecuador. 


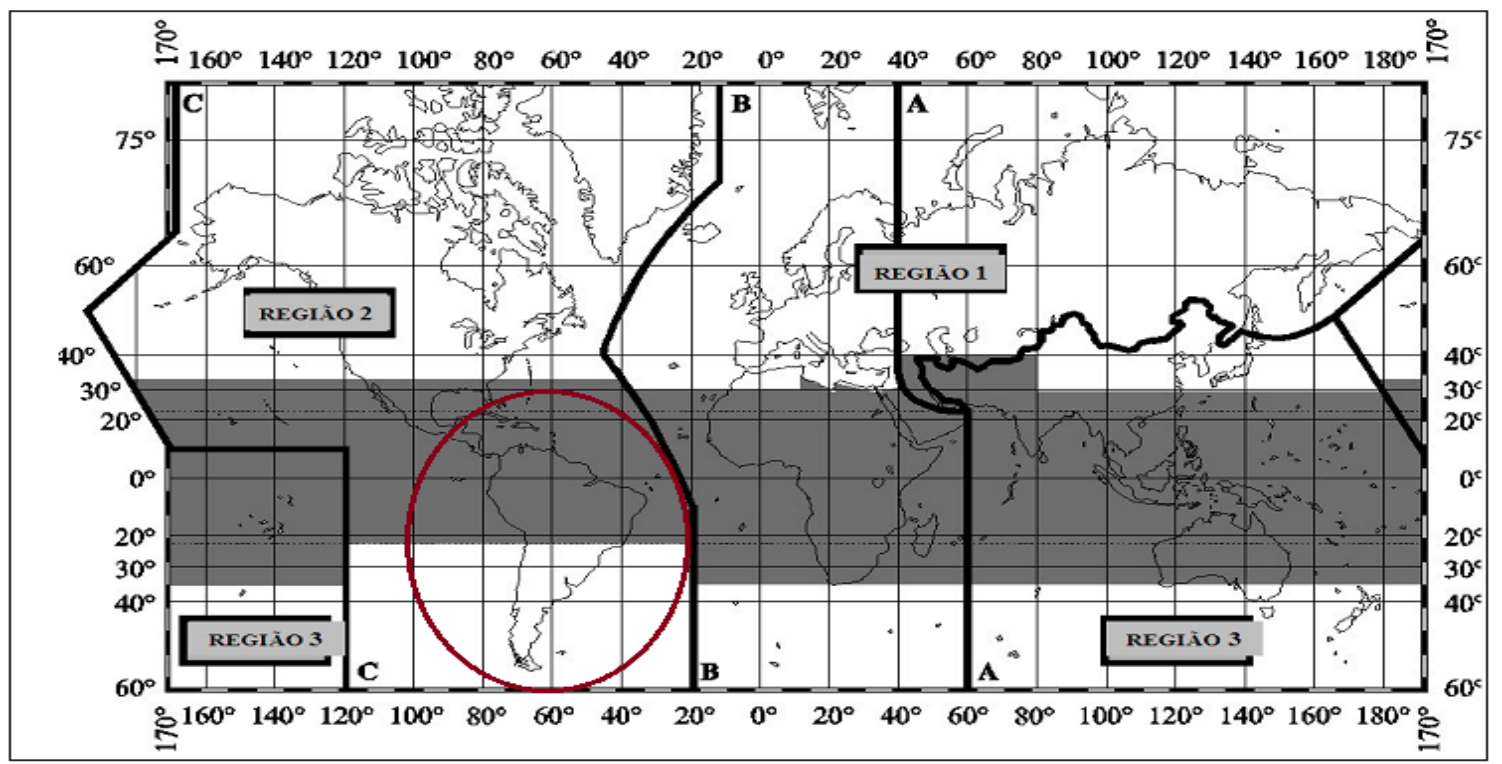

Figure 1.3 - Illustration of the Sub-Region 02 of the ITU-R - ALC. [1] 


\section{IV- Main Strategic Plan Objective:}

To Promote an LAC region Science \& Technology Cooperation Program it shall network the nation's select expert R\&D groups to plan and project the LAC Disaster Management and Reduction framework, as a joint venture international cooperation framework, anchored by the Union of South America Nations UNASUL, and the Community of Latin America and Caribe States CELAC.

\section{V- Specific Objectives, Main Actions:}

1-Promote the South America region technical scientific staff coordination's for the framework planning and full capacity building project supported by the Union of South American Nations UNASUR, in the short term 2014.

2-Extend the action 1 to the LAC region anchored by the Community of Latin America and Caribbean States CELAC, in the short term 2014.

3-Promote the cooperative Plan and Projects development of the National Platforms to full support Disaster Management and Reduction in the XXI century, in the medium term 2015.

4- Promote the cooperative South Region region platforms integration and pilot operation, in the medium term 2015.

5 - Extend action 4 to the LAC region in the medium term 2016.

\section{REFERENCES}

[1] - "Study of a space geostationary satellite system performance in the Ku and Ka microwaves bands to support a broadband telecommunication network for disaster management and reduction." Borgo, R. L. (2012). Dissertation in Electrical Engineering, Publishing PPGEE DM 497/2012. Department of Electrical Engineering, University of Brasilia, Brasilia, DF, 108p.

[2] - "Regional Latin America \& Caribbean Initiative for Disaster Management and Reduction in the XXI Century". (2013) Thesis Theme and LAC R\&D Framework. Borgo, R. L. Brasilia, March 2013. Article first published at "Terceiro Incluído" UFG/NUPEAT Magazine, vol. 02, p. $100,2013$.

[3] - "Framework Regional ALC para Gestão de Desastres no Século XXI”. AEB presentation on a PNAE meeting. Borgo, R. L. Brasília, 18 april 2011. 
[4] - “ La economía del cambio climático en América Latina y el Caribe. Síntesis 2010”. LC/G.2474 Copyright (C) Naciones Unidas, noviembre de 2010. Todos los derechos reservados Impreso en Naciones Unidas, Santiago de Chile.

[5] - “A practical framework for planning pro-development climate policy”. Copyright (C) United Nations Environment Programme, 2011.

[6]- "Povos Resilientes, Planeta Resiliente: Um Futuro digno de escolha”. Relatório do Painel de alto nível do secretariado-geral das Nações Unidas sobre sustentabilidade global.

2012 Nações Unidas 